\title{
Rho Exchange Factor ECT2 Is Induced by Growth Factors and Regulates Cytokinesis Through the N-Terminal Cell Cycle Regulator-Related Domains
}

\author{
Shin'ichi Saito, ${ }^{1}$ Takashi Tatsumoto, ${ }^{1,2}$ Matthew V. Lorenzi, ${ }^{1}$ Marcio Chedid, ${ }^{1}$ Veena Kapoor, ${ }^{1}$ \\ Hiromi Sakata, ${ }^{1}$ Jeffrey Rubin, ${ }^{1}$ and Toru Miki ${ }^{1,2 *}$ \\ ${ }^{1}$ Laboratory of Cellular and Molecular Biology, National Cancer Institute, Bldg. 37-1E24, \\ 37 Convent Dr., Bethesda, Maryland 20892-4255 \\ ${ }^{2}$ Molecular Tumor Biology Section, Basic Research Laboratory, National Cancer Institute, \\ Bldg. 37-1E24, 37 Convent Dr., Bethesda, Maryland 20892-4255
}

\begin{abstract}
The ECT2 protooncogene plays a critical role in cytokinesis, and its C-terminal half encodes a Dbl homology-pleckstrin homology module, which catalyzes guanine nucleotide exchange on the Rho family of small GTPases. The N-terminal half of ECT2 (ECT2-N) contains domains related to the cell cycle regulator/checkpoint control proteins including human XRCC1, budding yeast CLB6, and fission yeast Cut5. The Cut5-related domain consists of two BRCT repeats, which are widespread to repair/checkpoint control proteins. ECT2 is ubiquitously expressed in various tissues and cell lines, but elevated levels of ECT2 expression were found in various tumor cell lines and rapidly developing tissues in mouse embryos. Consistent with these findings, induction of ECT2 expression was observed upon stimulation by serum or various growth factors. In contrast to other oncogenes whose expression is induced early in G1, ECT2 expression was induced later, coinciding with the initiation of DNA synthesis. To test the role of the cell cycle regulator/checkpoint control protein-related domains of ECT2 in cytokinesis, we expressed various ECT2 derivatives in U2OS cells, and analyzed their DNA content by flow cytometry. Expression of the N-terminal half of ECT2, which lacks the catalytic domain, generated cells with more than $4 \mathrm{~N}$ DNA content, suggesting that cytokinesis was inhibited in these cells. Interestingly, ECT2-N lacking the nuclear localization signals inhibited cytokinesis more strongly than the derivatives containing these signals. Mutational analyses revealed that the XRCC1, CLB6, and BRCT domains in ECT2-N are all essential for the cytokinesis inhibition by ECT2-N. These results suggest that the XRCC1, CLB6, and BRCT domains of ECT2 play a critical role in regulating cytokinesis. J. Cell. Biochem. 90: 819-836, 2003. Published 2003 Wiley-Liss, Inc."
\end{abstract}

Key words: cell division; mitogen; serum induction; small GTPase; oncogene

The epithelial cell transforming gene 2 (ECT2) protooncogene was isolated from a mouse epithelial cell line BALB/MK as a cDNA clone, which confers transforming activity in fibroblasts through an expression cloning strategy [Miki et al., 1993]. The transforming activity of ECT2 is activated by the truncation of its N-terminal half. The C-terminal half

\footnotetext{
Abbreviations used: BRCT, BRCA1 C-terminal; CLB6, cyclin B6; Cut5, cells untimely torn 5; DH, Dbl homology; ECT2, epithelial cell transforming gene 2 (human); ect2, mouse ECT2; ECT2-N, N-terminal half of ECT2 protein; EGF, epidermal growth factor; GFP, green fluorescent protein; HGF, hepatocyte growth factor; IGF-I, insulin-like growth factor I; KGF, keratinocyte growth factor; $\mathrm{PH}$, pleckstrin homology; SF, scatter factor; TGF- $\beta$, transforming growth factor- $\beta$

Grant sponsor: Japan Society of Promotion of Sciences fellowships (in NIH).

Shin'ichi Saito's present address is Laboratory of Cell Biology, National Cancer Institute, Bethesda, MD.

Takashi Tatsumoto's present address is Fukuoka Teishin Hospital, 2-6-11 Yakuin, Chuo-ku, Fukuoka 810-8798, Japan. Published 2003 Wiley-Liss, Inc. ${ }^{\dagger}$ This article is a US Government work and, as such, is in the public domain in the United States of America.
}

Matthew V. Lorenzi's present address is Oncology Drug Discovery, Pharmaceutical Research Institute BristolMyers Squibb, P.O. Box 4000, Princeton, NJ 08543-4000.

Hiromi Sakata's present address is Institute of Artificial Organ, Transplantation and Gene Therapy, Sapporo Hokuyu Hospital, 6-6 Higashi Sapporo, Shiroishi-ku, Sapporo 090-8666, Japan.

*Correspondence to: Toru Miki, Building 37 Room 1D22, National Institutes of Health, 37 Convent Dr. MSC 4255, Bethesda, MD 20892-4255. E-mail: toru@helix.nih.gov Received 27 June 2003; Accepted 15 August 2003 DOI $10.1002 /$ jcb.10688 
of ECT2 contains Dbl homology (DH) and pleckstrin homology $(\mathrm{PH})$ domains, which are found in guanine nucleotide exchange factors of the Rho family of small GTP-binding proteins. The Rho family of small GTPases, represented by RhoA, Rac1, and Cdc42, function as molecular switches of diverse biological functions, such as cytoplasmic actin reorganization, cell motility, cell scattering, cytokinesis, lymphocyte coaggulation, smooth muscle contraction, and superoxide generation [Van Aelst and D'Souza-Schorey, 1997; Hall, 1998]. The GTP-bound form of Rho proteins is active, whereas the GDP-bound form is inactive. Activation of the Rho proteins is promoted by guanine nucleotide exchange factors (GEFs), which catalyze the replacement of bound GDP by GTP. The GTP-bound form of Rho proteins can specifically interact with their effectors or targets and transmit signals to downstream molecules. Rho proteins are inactivated through the hydrolysis of bound GTP to GDP by the intrinsic GTPase activity, assisted through GTPase activating proteins (GAPs).

We have shown that ECT2 catalyzes guanine nucleotide exchange on RhoA, Rac1, and Cdc42 in vitro [Tatsumoto et al., 1999]. ECT2 is a nuclear protein in interphase cells and then disperses in the cytoplasm after nuclear membrane breakdown. ECT2 is phosphorylated in G2 and M phases of the cell cycle. In M phase, ECT2 is localized in the mitotic spindle. During cytokinesis, ECT2 is localized in the midbody. Inhibition of the ECT2 function, either by microinjection of affinity-purified anti-ECT2 antibody or expression of a dominant-negative form of ECT2 (ECT2-N), strongly inhibits cytokinesis. A Drosophila gene pbl, whose mutation renders cells defective in cytokinesis during embryogenesis, encodes an ECT2related protein [Prokopenko et al., 1999]. Therefore, ECT2 regulates cytokinesis from fly to humans. The level of GTP-bound, active form of Rho, does not change from S phase to prometaphase, but increases thereafter and reaches to a peak at telophase. ECT2 appears to play a critical role in the Rho activation during cytokinesis, as a dominant negative ECT2 efficiently inhibits the elevation of active Rho during cytokinesis [Kimura et al., 2000]. ECT2 expression is induced in regenerating mouse liver after hepatectomy [Sakata et al., 2000]. Through somatic cell analysis and FISH, we have mapped the human ECT2 gene to 3q26.1q26.2 [Takai et al., 1995].

In this report, we show high levels of ECT2 expression in various tumor cell lines and rapidly proliferating cells in embryonic tissues. Consistent with this finding, ECT2 expression was regulated by serum and various mitogens. We also report that cytoplasmic localization of ECT2-N strongly enhances its activity to inhibit cytokinesis. Finally, we found that the cell cycle regulator-related domains are essential for the inhibition of cytokinesis by ECT2-N.

\section{MATERIALS AND METHODS}

\section{DNA Constructs}

Human ECT2 cDNA was isolated from a B5/ 589 human mammary epithelial cell cDNA library using the mouse ect $2 \mathrm{cDNA}$ as probe. The entire nucleotide sequence of the longest cDNA insert (clone 1M) was determined. This cDNA (4,349 nucleotides) contained a large open-reading frame encompassing 2,649 nucleotides (882 amino acids) beginning with a methionine coden at position 44S and ending with a TGA termination coden at position 3091, and was flanked by $5^{\prime}$ - and $3^{\prime}$-untranslated regions. The segment was degssiter GenBank (Accession no. AY376439).

ECT2 N-terminal fragments were amplified by PCR using ECT2 clone $1 \mathrm{M}$ as template and subcloned between BamHI and EcoRI sites of the mammalian expression vector pcDNA3 (Invitrogen, CA) or pCEV29F3 [Lorenzi et al., 1999]. A small deletion was introduced in the Clb6-homology domain of ECT2-N4 by digestion with $B s p E I$ and EcoNI followed by blunt-end ligation. The THL to AAA mutations in the BRCT-1 and BRCT-2 domains were introduced by PCR using mutant primers. pEGFP-C1 was from Clontech, CA. All constructs generated by PCR were sequenced to ensure no mutation occurred except the designed mutations.

\section{Cell Culture}

U2OS cells were grown in modified McCoy's $5 \mathrm{~A}$ medium supplemented with $15 \%$ fetal bovine serum. Other cell lines were maintained in Dulbecco's modified minimal essential medium (Invitrogen, CA), supplemented with $10 \%$ fetal bovine serum, $100 \mathrm{nM}$ glutamine, and penicillin/streptomycin in a humidified atmosphere with $5 \% \mathrm{CO}_{2}$. For growth factor treatment, $\mathrm{NIH} /$ 3T3 mouse embryonic fibroblasts and Balb/MK 
mouse epidermal keratinocytes were switched to serum-free medium [1:1 $(\mathrm{v} / \mathrm{v})$ mixture of Dulbecco's modified Eagle's medium (DMEM) and Ham's F-12 medium, supplemented with $5 \mu \mathrm{g} / \mathrm{ml}$ transferrin and $30 \mathrm{nM} \mathrm{Na} \mathrm{NeO}_{3}$ ] and incubated overnight. The growth factors used in this study were all human recombinant proteins. KGF and $\mathrm{HGF} / \mathrm{SF}$ were purified as previously described [Ron et al., 1993; Cioce et al., 1996]. TGF- $\beta$ was purchased from R\&D (Minneapolis, MN). EGF and IGF-I were from Pepro Tech, Inc. (Rocky Hill, NJ). DNA synthesis was assessed by measuring ${ }^{3} \mathrm{H}$-thymidine incorporation as described [Rubin et al., 1989].

\section{Cell Cycle Analysis by Multi-Parameter Flow Cytometry}

Cells $\left(10^{6} /\right.$ dish) were seeded in 10 -cm dishes and cotransfected following day with $10 \mu \mathrm{g}$ of the indicated expression vector DNA and $1 \mu \mathrm{g}$ of the selection marker plasmid pcDNA3-CD56 [Saito et al., 1994]. At the indicated time points, cells were washed once with phosphate buffered saline (PBS) and once with PBS containing $0.1 \%$ EDTA, and then incubated in PBS containing $0.1 \%$ EDTA for $5 \mathrm{~min}$ at $37^{\circ} \mathrm{C}$ to detach from plates. The detached cells were collected by centrifugation, resuspended in $100 \mu \mathrm{l}$ of medium containing $4 \mu \mathrm{g}$ of ITK-2 (anti-CD56 antibody) [Saito et al., 1991], and then incubated on ice for $30 \mathrm{~min}$. After washing twice with medium, cells were incubated with FITCconjugated anti-mouse IgG (Roche, IN) on ice for $20 \mathrm{~min}$, followed by washing twice with PBS. For cell cycle analysis, cells were fixed and stained with propidium iodide. At least 5,000 of CD56 positive cells were analyzed by a flow cytometer.

\section{Immunoblot Analysis}

Western blot analysis was performed with a polyclonal rabbit ECT2 antibody as previously reported [Tatsumoto et al., 1999]. Briefly, membranes were first blocked with $5 \%$ nonfat dry milk in PBS-Tween buffer $(1.5 \mathrm{mM}$ $\mathrm{NaH}_{2} \mathrm{PO}_{4} \cdot \mathrm{H}_{2} \mathrm{O}, 8 \mathrm{mM} \mathrm{Na}_{2} \mathrm{HPO}_{4}, 0.15 \mathrm{M} \mathrm{NaCl}$, $\mathrm{pH} 7.4,0.1 \%$ Tween-20), and rinsed in PBS-T. Next, the membranes were stained for $90 \mathrm{~min}$ at room temperature with a 1:2,000 dilution of affinity purified anti-ECT2 antibody. In addition to ECT2, separate membranes were probed with a 1:2,000 dilution of $\alpha$-tubulin antibody. Bound antibody was detected by chemiluminescence using an ECL detection kit (Amersham).

\section{In Situ Hybridization}

In situ hybridization, studies for the detection of ect2 transcript were performed as described [Fox and Cottler-Fox, 1993]. Briefly, 6- $\mu \mathrm{m}$ sections of formaldehyde fixed liver from Balb/c mice and 14-day-old embryos from C57BL/6 mice were prepared and mounted on silanized slides. The slides were cleared and prehybridized with ${ }^{35}$ S-labeled sense or antisense probes prepared from ect2 CL7 cDNA [Miki et al., 1993] as template. Some of the sections were also digested with proteases prior to hybridization. The slides were washed, dried, and coated with NBT2 Kodak emulsion. After 4-day exposure, the slides were developed and stained with hematoxylin and eosin. In all cases, background levels were within the acceptable range. Slides were examined with low power dark field and bright field microscopy.

\section{Serum Induction of ECT2 in T98G Cells}

T98G (ATCC CRL-1690), a human glioblastoma cell line, was obtained from the American Type Culture Collection (Manasas, VA) and cultured in Dulbecco's modified minimal essential medium (DMEM) (Invitrogen Corp., Carlsbad, CA) supplemented with $10 \%$ fetal bovine serum, $100 \mathrm{nM}$ glutamine and penicillin/streptomycin. For synchronization, T98G cells at $70 \%$ confluence were placed in medium containing $0.1 \%$ fetal bovine serum (FBS) for $72 \mathrm{~h}$, then split at the 1:3 ratio and released from starvation arrest by the addition of FBS to a final concentration of $10 \%$. Progression through the cell cycle was monitored by measuring DNA content with flow cytometer as described. Samples were harvested at the indicated times and analyzed by Northern blotting with ECT2-N4 cDNA probe or Western blotting using anti-ECT2 antisera, anti-cyclin B1 (Santa Cruz, GNS1), anti-CDC2 (Santa Cruz, 17), and anti- $\alpha$-tubulin (Oncogene Research Products, $\mathrm{Ab}-1)$.

\section{RESULTS}

\section{N-Terminal Domain of ECT2 Is Related to Cell Cycle Regulators}

We isolated human ECT2 using murine ect2 cDNA as template (Fig. 1). The structure of human ECT2 cDNA has been briefly reported [Tatsumoto et al., 1999]. Comparison of human 
A

\begin{tabular}{|c|c|c|c|c|c|c|c|}
\hline \begin{tabular}{l|l|}
$N$ & $X R C C 1$ \\
\end{tabular} & CLB6 & \begin{tabular}{|l|l|}
\multicolumn{2}{|c|}{ Rad4/Cut5 } \\
BRCT1 & BRCT2 \\
\end{tabular} & $S$ & DF & \multicolumn{2}{|c|}{$\mathrm{PH}$} & C \\
\hline
\end{tabular}

B
1

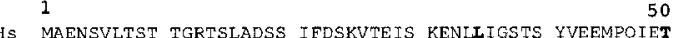
Mm

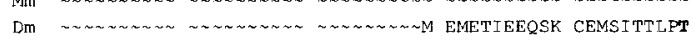

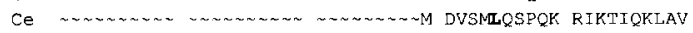
51
HS RVILVQEAGK QEELIKALKD. IKVGFVKME SVEEFEGLDS PEFENVIVVT

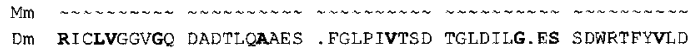
Ce SKKDVHDFKD IFEMLEEQRE KENINIIQYD SLDDLSGDWS ...EYTEFCG
100
143
HS DFODSVENDL YKADCR... VIGPPVULNC SQKGEPLP. FSCRPLYCTS

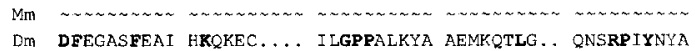
Ce NFDSDLFRTL TKHQETQALF IIGASVLKNK LLKNEDLMTL RAARPLYCEL
144
*** 192
HS MMNLVCFTG . ERKKEELVK LVTIVHHMGG VIRKDENSKV THLVANCTOG
Mm MLNLVLCETG . FRKKEELLVK IVTLVHHMGG VIRKECNSKV TELVANCTQG
Dm MRGVVTCFTG . IRKKDELTK LVNIIHSMGG CIKKDLNTKT THLICNHSGG
Ce MKDVTMKLAA EVPNKRE... LVDLVHYMGG SVRKDTVSRT NVF IAAKVEA
HS EKERVAVSLG TPIMKPEWIY KANERRNEQD FYAAVDDFRN EFKVPPFQDC
$\begin{array}{lr}193 & 242 \\ \text { HS EKERVAVSLG TPIMKPEETY KAWERRNEQD FYAAVDDFRN EFKVPPFQDC }\end{array}$
MII EKFRVAVSLG TFIMKPEWIY KAWERRREQC ECAAVDDFRN EFKVPFFQDC
DM EKYOYAKTFR LTVVRPAWF AAWADRNSLE FDATQENETK THRLKAFEGQ
Ce .KVQSISLVG VPTMRADWVT ECWKHRDDSY FDVMEPCEVD KHRLGVEEGL 243
$\star \star \star \star 291$
HS ILSFLGFSDE EKTNMEEMTE MQGGKYLPLG DERCTHLVVE . ENIVKDLPF
MM ILSFLGFSDE EKHSMEENTE MQGGSYLPVG DERCTHLIVE , ENTVIOLPF
DE KICFFGFPVE EHQHMVDVLL ENGGVCAELD DPECSHVVVD . EHTTLTKPE
Ce SLFEHGFKOT EIDDMLKSLE NTGGKIAP.S PTLATHWYM PDNDEVETLA 292
336
HS EPSKKC YVVK QEWFWGSIOM DARAGETMYL Y.... EKAN TPELKKSVSM
Mm EPSKKLFVVK QEWEWGSIQM DARAGETMYL Y. . . . EKAN TPELKKSVS $L$
DM PKNNHTHILK SDWFWTIQ. NGYANEMDYL FGDYLDSITN TPNTDRRDSL
Ce VSSNQVHVTK , EWFWVSLHR GCCAIEDNFA LF....... TGKIHRKPLE 337
$\begin{array}{llr} & 337 & 384 \\ \text { HS } & \text {.ISLNTPNSN RKRRRLKETL AOLSRETDVS PFPPRKRPSA EHSLSI. GSL } \\ \text { Mm } & \text {.LSLSTPNSN RKRRRLKETL AQLSRETDLS PFPPRKRPSA EHSISI.GSL }\end{array}$
Mm .ISLSTPNSN RKRRRLKETL AQLSRETDLS PFPPRKRPSA EHSISI.GSL
DM PISFN. ... K RKRKRFSQRI .QL. EGTPLG SGKRRSSVSD AGLLSVSNSL
Ce SSSVSSPIGK SIRSQNSRSL SSMRD............. CSVEGPT 385
HS LDISNTPESS INYGDTPKSC TKSSKSSTPV PSKQSARWQV AKELYYTESN MII IDISNTPESS IHYGETPKSC AKSSRSSTPV PPKQSARWQV AKELYQTESN
DM FDCTTSPDKL ....ESDKL.L HAEPEASDAT PAKKSMRFNE FMDFYTTESN
Ce .SLNMTPDYI YSNDDVENSC KS ....... PRQPSKRLRV CNEMVETEKN 435
483
HS YVNILATIIQ LFQVPLEEEG QRGGPILAPE EIKTIFGSIP DIFDVHTKI.
Mm YVNILATIIQ LFQVPLEEEG QRGGPILAPE EIKTIFGSIP DIFDVHMKI
Dn YVGILDTILN LFKNKLEELA ETNDPLINKS EIKTIFGNFL PIHEVHQSM,
Ce YLSLLKLVVR ,FKEAIECEI SHNE. FMSRS DVAMMEGKLD PILELAERIF $484 \quad 521$
HS $\ldots \ldots$ KDDL EDLIV.... . NWDESKSIG DIFLKYSKDL VKTYPPFVNF Mm $\ldots \ldots$ KDDL EDLIA .... NWDESRSIG DIFLKYAKDL VKTYPPFVNF
DM ..... IEHL RKLHA.... . NGREDCLIG DIIIQHRDEL IKAYPPYVNF
Ce ARLTVMSNEA NTLLTVVNGK KNDDKNLDFA QVWIDAKEEM KKAYPOYINS

Fig. 1. Structure of human ECT2 protein deduced from the CDNA sequence. A: Schematic representation of ECT2 protein. BRCT, BRCA1 C-terminal repeat; CLB6, Cyclin B6 homology; $\mathrm{DH}, \mathrm{Dbl}$ homology; $\mathrm{PH}$, pleckstrin homology, S, small central domain. B: Comparison of amino acid sequences of ECT2 homologs of different species. The predicted amino acid sequence of human ECT2 $(\mathrm{Hs})$ was compared with mouse Ect2 (Mm; [Miki et al., 1993]), Drosophila Pbl (Dm; [Prokopenko et al., 1999]), and C. elegans T19E10.1b (Ce; accession no. Z46795). Amino acid residues identical to those of human ECT2 are shown in bold. Amino acids are numbered from the first methionine coden

ECT2 with related molecules revealed that murine ect2 is the most closely related molecule (95\% similarity, $84 \%$ identity at the amino acid level), although the human clone contained
522 HS FTMSKETIIK CEKOKPRFAA FLKINOAKPE CGROSLVELL IRPVORLPSV Mm FBMSKEMIIK CEKOKKRRFHA FLKINQAKPE CGRQSLVELL IRPVQRLPSV Dm FEQMKEOLQY CDREYPRFHA FLKINQTKPE CGRQGLQDLM IRPVQRLPS I Ce YDTIKRLFDR ODRENSKFHT FCKAKESNPE FHRLKLTDLM VKPVQRLPSV 572 572
HS ALLLNDLKKCH TADENPDKST LEKAIGSLKE VMTHINEDKR KTEAOKOIFD MII ALLLNDLKKX TADENPDKST LEKAIGSIKE VMTHINEDKR KTEAQKQIFD Dm SLLLNDILKH TTSGNADHGR LEEALKAIKO VTLHINEDKR RTESRMAIFD Ce ILLLKEMAK. . KSDSKLKNN AEEAAKATDE VLKTANKTRE KNDNFISHLS 622 669 HS VVYEVDCC NLTSSHRSTV ORVETISIGE HPCDRGE O VTLFIFNDCI Mn VVYEVDGCPA NLLSSHRSLV QRVETVSLGE HPCDRGE. . Q VTLFLFNDCL DM IFNDIEGCPA HLVSSNRSF I LKCEVNELSD SLSGRGD. . S LVLYLFSDSI Ce KFTDIENVPF ILVAANRMFI RELVVSPIAS TSPGLQEAK MKLFLFHDVI

$$
670
$$

HS EIARKRHKV . ....... IGT FRSPHGOTRP PASLKHIHLM PLSOIKKVLD

Mm EIARKRHKV. . . .... IGT FRSPHDKTRP PASLKHIHLM PLSQIKKVLD DM ELCKRRSKG. . . . . . FNT AKSP.... ST AKTHKHLKII SLNTIRIVID Ce IITKIRSEKN TMQRLARHAS FASLHSRQRR P. YYRYIDQI QLNTMRSAFR

$$
712
$$

HS IRETEDCHNA FALLVRPPTE OANVLLSFOM TSD........ ELPKENW

Mn I IRETEDCHNA FALLURPPTE QANVLLSFQM TSE......... Dm I... SDSPRA FGLLLRGDKE K...LYTETI SDE.......... . ETDKSVY Ce IRAPDETAKC LELQRQNGST KPNVFUWCLI HRDEQGGDID TVEESNDDEE

$$
752
$$

HS LKMLCRHVAN TICKADAENL IYTADPESF. EVNTKDMD.S TLSRASRAIX

MM LKMLCRHVAN TICKADAENL MYVADPESF. EVNTKDMD.S TLSRASRAIK

DM VKKLCNQIAA HTCETDADKL LICRTSQEL. EVDISDVNVS TLSKAFKLAA

Ce VRDFLDDINY KIL.,SDCGRF FYSSDPSDMN EINDAMVSDM T. TRYFRNLC

$$
800
$$

HS KTSKKYTTRAF SFSKTP. . K RALRRALMTS HGSVEGRSPS SNDKHVMSRI

$M$ KTSKKNVTRAF SFSKTP... K RALRMALSSS HSS. EGRSPP SSGKLAVSRL

DM KTRLKVGRAF SFNKTPNKLK RAVSTMMTSP FGSTNSLTPA S.. QLAQMRI

Ce GAKPOYGHGS OMNTTVSE.. .....RSTQNE WSHNESFMPP PQSOSRMRRA 847 882

HS SSTSSLAGIP SPSLVSLPSF FERRSHT. . . LSRSTTHLI

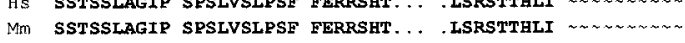
DW ASCTNINEVD DEDCASW... ...RSSS... . PSTQSEMLV VPPLSVQPTK Ce FSNAOL.... . . TLATTLGI GRNOSRNHLG QINENTTFLQ SPRVSCDPAA

Hs

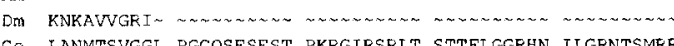

CE LANMTSVGGL PGCQSESEST PKRGIRSRLT STTFLGGRHN ILGRNTSMRR$$
1001
$$$$
1025
$$

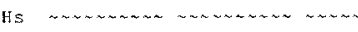

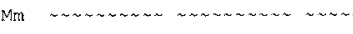

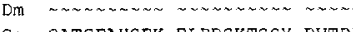

Ce QATGFAHSEK ELPRSKTSSY RVTDI

of human ECT2. ", ," not present in the sequence; ".," a gap introduced to maximize the alignment. The positions of the BRCT1 and BRCT2 mutations are shown by "****" (see Fig. 9A). C: Structural similarity of the N-terminal domain of ECT2 with related proteins. The human Rad4-like gene (accession no. D87448), C. elegans genes F37D6.1 (Z75540) and T19E10.1 (Z46795), and fission yeast Rad4/Cut5 (D16627), were first identified as proteins related to the N-terminal domain of ECT2 using BLAST, and then aligned by PILEUP in the Wisconsin package. Amino acid residues identical to those of human ECT2 are shadowed. Gaps are introduced to maximize the alignment.

an additional stretch of 150 amino acids at its $\mathrm{N}$-terminus. T19E10.1b, an open-reading frame identified by a Caenorhabditis elegans genome project, and pebble [Prokopenko et al., 1999], 


\begin{tabular}{|c|c|}
\hline & 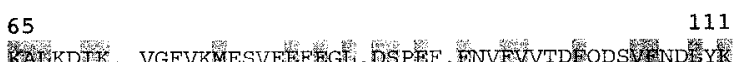 \\
\hline & 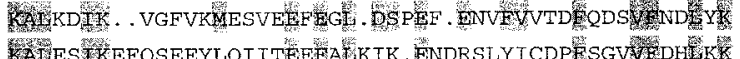 \\
\hline 4-ike & 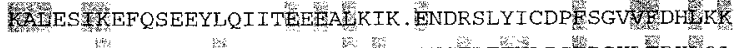 \\
\hline $7 D 6.1$ & NLEELFKTAKAVGIMPEWIDSDAFEWL . QKSEDFF \\
\hline E10.1 & L $\mathrm{RTTS} T$ \\
\hline & $\cdots$ \\
\hline & 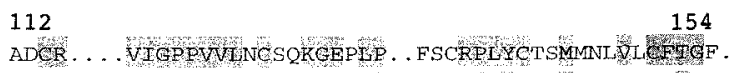 \\
\hline 24-like & ...VVEPQWVIFCMHHQRCV . RAEHPVWNMVISDVTISCWSLE \\
\hline $7 D 6.1$ & RKLK . . . VYG \\
\hline $9 \mathrm{E} 10.1$ & TLRAARPLYCELMKDVTMKLAAEV \\
\hline $4 /$ CUT5 & SSSKPLKGFYICCOSID \\
\hline ст2 & 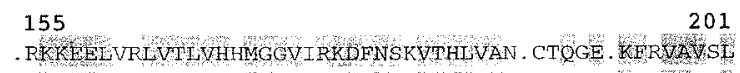 \\
\hline D4-like & KEKREEVHKYVOM. . MGGRVYRDLNVSVTHHL IAG . EVGSK. KYLVAANE \\
\hline 706.1 & LTKROEHYEKIGW. . MCEVVGD \\
\hline 19210.1 & PAKRE. . WODUVEYMGGSVRK \\
\hline UT5 & LKQRTEISTKAR. . KLGAAYRSDFTK \\
\hline СТ2 & 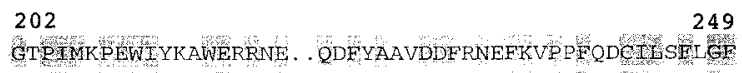 \\
\hline D4-like & KKPILLPSWHKTLWEKSOE. . KKIT \\
\hline $7 D 6.1$ & WETSQTTMGRA \\
\hline $9 \mathrm{E} 10.1$ & STEFH \\
\hline $\mathrm{D} 4 / \mathrm{CUT} 5$ & DIKMIMSSEWIPVLYBSWV . . QGEDLDDGLLVDKHELPTLFKQFVCLTNI \\
\hline $\mathrm{T} 2$ & $\begin{array}{l}250 \\
\text { SDEEKTMMEFMTEMOGGK LP EGDER. }\end{array}$ \\
\hline$D 4-1 i k e$ & CGLDRKEVQQLTVKHGSOYYMGQEKKMNE. \\
\hline $7 \mathrm{D} 6.1$ & DGADRTHFIQLIEDHGGKVPGTMSKTRFFFSVFHYK ICSFLGALUS IQMM \\
\hline $9 E 10.1$ & KQTEIDDMLRSLENTGGKLAPSPT $\ldots \ldots \ldots \ldots \ldots$ LARTHWYNPD \\
\hline D4/CUT5 & GQPERSRIENYVLKHGGTFQPDITRD $\ldots \ldots \ldots \ldots \ldots$ VIHILAGT \\
\hline & \\
\hline & \\
\hline D4-like & . PKGQKYECAKRWNWHCYTTQWFDSTEK . . . . . GFCQDESIYK \\
\hline $7 \mathrm{D} 6$. & LPEKAFY . . RKYHPKYLTADHIRS STPKRDANVTE . . . SVPDISSTAG \\
\hline & SLHRGCCA IEDNFALPI \\
\hline$A / C U$ & RNAYTEPQYFQI \\
\hline
\end{tabular}

Fig. 1. (Continued)

a recently identified Drosophila gene which regulates cytokinesis, exhibited similarities along with the entire coding sequence, suggesting that these genes are C. elegans and Drosophila melanogaster orthologs of human ECT2, respectively.

The N-terminal half of ECT2 was homologous to several cell cycle control proteins. Amino acids 76-139 exhibited homology to a yeast B-type cyclin, Clb6 [Schwob and Nasmyth, 1993] (29\% identity, 54\% similarity). This Clb6 homology region is followed by another domain that consists of two direct repeats and exhibits similarity to a fission yeast cell cycle regulator, Rad4/Cut5 [Saka and Yanagida, 1993]. Rad4/Cut5 is required for S phase entry as well as inhibition of $\mathrm{M}$ phase entry before completion of DNA synthesis, and plays a critical role in replication checkpoint control [Saka et al., 1994]. The Cut5-homology domain of ECT2 consisted of two BRCA1 Cterminal (BRCT) repeats, which are widespread in DNA damage-responsive cell cycle checkpoint or DNA repair proteins [Bork et al., 1997]. The ECT2 BRCT repeats were also related to those of the human topoisomerase II-binding protein TopBP1 [Yamane et al., 1997] and a human repair protein XRCC1 [Thompson et al., 1990]. Besides the BRCT homology, the very N-terminal region of ECT2 (amino acids 24-60) also exhibited another homology to XRCC1, and this region is designated XRCC1 homology domain (Fig. 1A). In addition to these genes, three genes identified by genome projects were found to exhibit sequence similarity to the ECT2 Nterminal domain (Fig. 1C). Among them, the human Rad4-like gene (accession no. Z46795) was most homologous to ECT2 in this region (28\% identity, $46 \%$ similarity) in an overlap to 
300 amino acids. A C. elegans gene identified by a genome project, F37D6.1 (accession no. Z75540), also contained structural similarity with the Nterminal region of ECT2. These results indicated that the combination of XRCC1, Clb6- and Rad4/ Cut5-homology domains are well conserved in species and may exhibit cell cycle control functions in these organisms.

\section{ECT2 Is Expressed at High Levels in Various Tumor Cells}

To investigate the possible involvement of ECT2 in human tumorigenesis, ECT2 expression in human tumor cell lines was examined by Northern blot hybridization (Fig. 2A). RNAs from normal cells, a human embryonic fibroblast cell line M426 and a breast epithelial cell line B5/589, were included in each blot as controls. The human ECT2 cDNA probe detected a single message of $4.4 \mathrm{~kb}$ in normal as well as tumor cell lines. Interestingly, the majority of tumor cell lines showed higher ECT2 mRNA expression than the normal cells. In particular, liver, lung, bladder, and ovarian tumor cells showed high levels of ECT2 expression. A lung cancer cell line, A549, showed the highest ECT2 expression among all the cell lines tested. Whereas, higher expression was found in many tumor cells when compared to normal cells, no significant change in the size of ECT2 transcripts was observed. The cells showing higher ECT2 mRNA expression levels were subjected to Western analysis to test the protein expression levels. As shown in Figure 2B, several tumor cell lines expressed ECT2 protein at higher levels than normal fibroblasts (M426) or epithelial cells (B5/589). The lung carcinoma cell line, A549, which showed the highest ECT2 mRNA expression, also showed the highest protein expression. Several cell lines including HA188 (lung carcinoma), KATO III (gastric carcinoma), SKLMS (leiomyosarcoma), A431 (epidermoid carcinoma), and C33A (cervical carcinoma) also showed high levels of ECT2 protein expression. To test whether overexpression of ECT2 in these cells is attributed to gene amplification, genomic DNA was extracted from A549, HA146, HA188, HA1182, SW1271, and KATO III cells as well as B5/589 for a control. The DNAs were digested with EcoRI or HindIII and subjected to Southern analysis using ECT2 cDNA as probe. However, no alteration of intensity or size of the bands was detected (data not shown), indicating that the ECT2 overexpres- sion is not due to the amplification of ECT2 locus in these cells.

\section{ECT2 Is Expressed at High Levels in Rapidly Proliferating Cells During Fetal Development}

We previously reported that ect 2 is expressed in limited numbers of adult mouse organs including kidney, liver, spleen, and testis and is not detected in brain, heart, lung, and skeletal muscle [Miki et al., 1993]. In order to determine the tissue distributions of the ect2 transcripts during embryonic mouse development, serial sections of 14-day mouse embryo were examined by in situ hybridization. As shown in Figure 3A, strong signal of ect 2 mRNA was detected in brain, specifically in ventricular zone, olfactory lobe, and diencephalon. Ect2 was also expressed in hematopoietic organs such as fetal liver and thymus, and proliferating epithelial cells including nasal cavity and gut. Moreover, we found ect 2 expression in primordia of tooth, costal cartilage, heart, lung, and pancreas. No specific hybridization was seen using sense strand probes (Fig. 3B). These results indicate that ect 2 mRNA expression occurs at sites of active cell proliferation in the developing organism.

\section{ECT2 Expression Is Induced From $\mathrm{S}$ to $\mathrm{M}$ Phases by Serum}

High level expression of ECT2 in tumor cell lines and rapidly proliferating cells in embryonic tissues suggested that ECT2 expression is accompanied by rapid proliferation. Together with the presence of cell cycle regulator homology domains, ECT2 expression may be regulated in a cell cycle specific manner. To test this possibility, confluent monolayers of M426 lung embryonic fibroblasts were cultured for $24 \mathrm{~h}$ in serum-free medium and then switched to culture medium containing $10 \%$ fetal bovine serum. As shown in Figure 4A, whereas antiECT2 stained serum-starved cells very faintly, the strong signal was detected in the nuclei of serum-induced cells. This staining was efficiently blocked when the antibodies were preincubated with recombinant ECT2 (data not shown), indicating that the staining was specific to ECT2.

To determine in which stages of the cell cycle ECT2 is induced, we synchronized T98G human glioblastoma cells and followed the ECT2 expression in the cell cycle. As shown in 
A
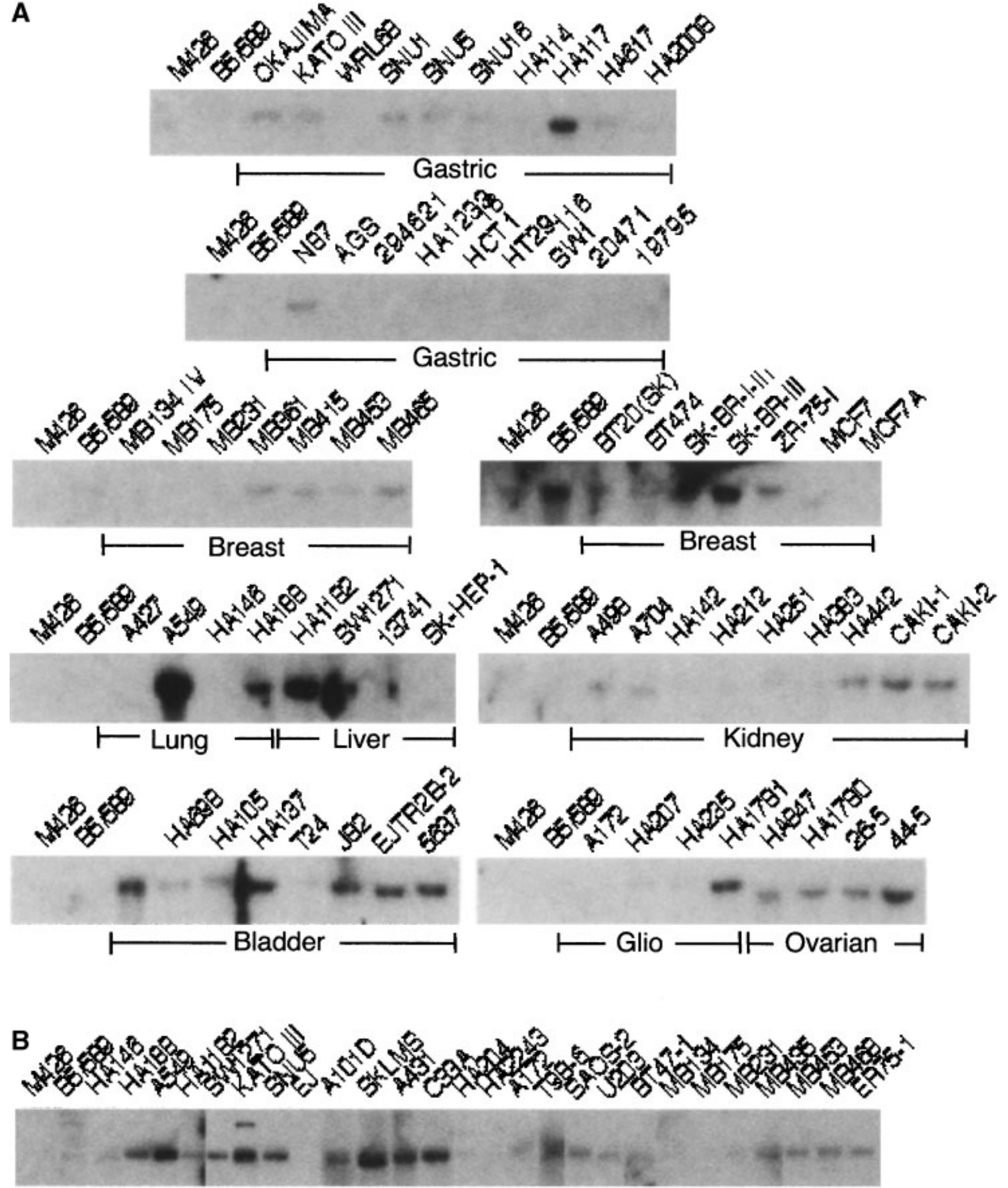

Fig. 2. Expression of ECT2 in human tumor cell lines. A: ECT2 mRNA expression in human tumor cell lines. RNA was extracted from the indicated cell lines, separated on a formaldehyde gel, and blotted onto a membrane. Each panel represents a single blot and the RNAs from two normal cell lines, M426 (lung fibroblasts) and B5/589 (epithelial cells), were included in each blot for references. The blots were hybridized with a 1.6-Kb Sall fragment containing the 3 -half of the human ECT2 CDNA $1 \mathrm{M}$ as probe. Equal loading of the RNA samples was confirmed by staining the rRNA species. B: ECT2 protein expression in human tumor cell lines. Lysates were prepared from the indicated cells, separated by SDS-PAGE, and blotted onto a nitrocellulose membrane. The blots were probed with anti-ECT2 antibody and visualized by a chemiluminescent system. 

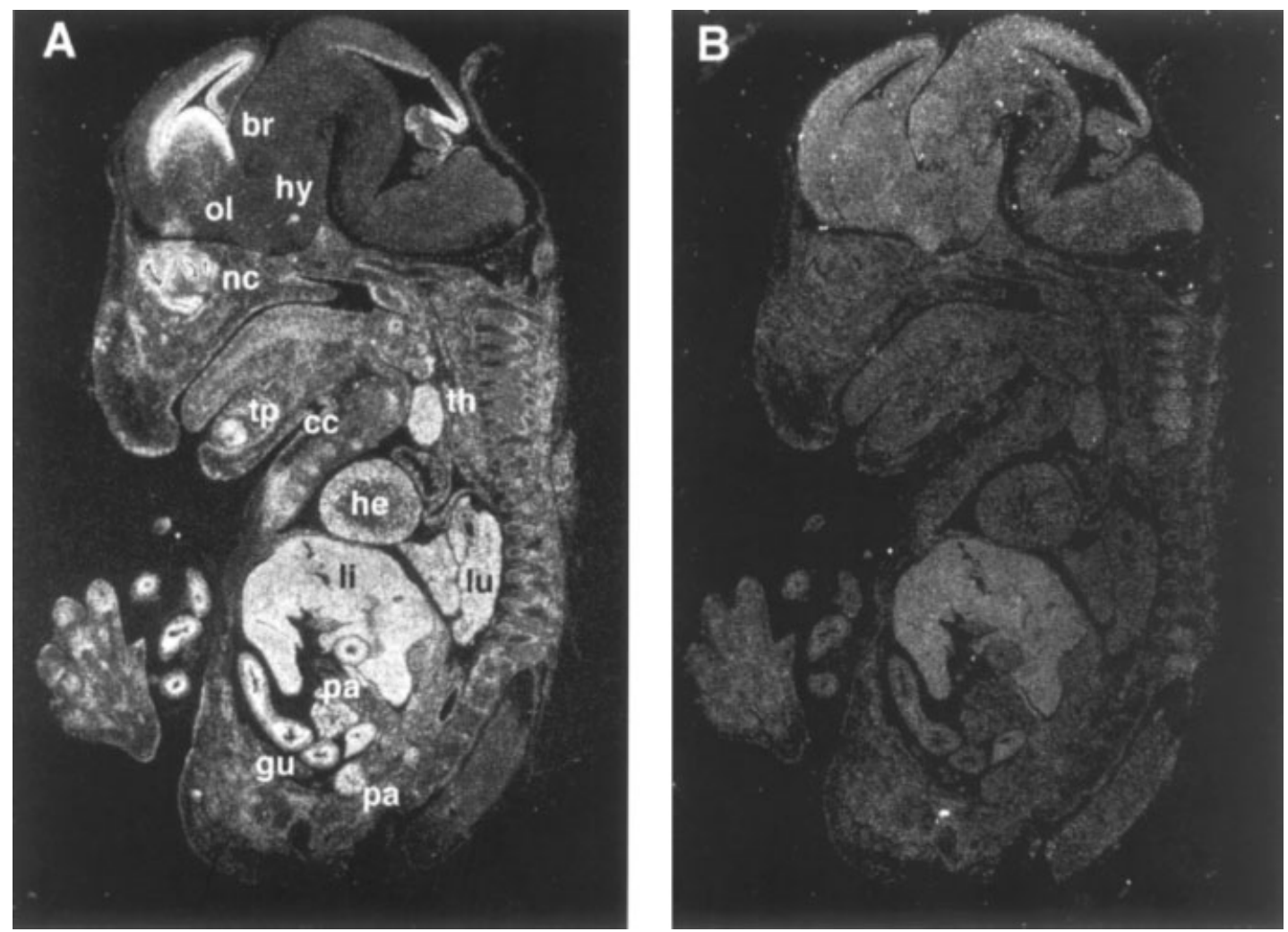

Fig. 3. Expression of ect $2 \mathrm{mRNA}$ in mouse embryos. A sagittal section of a 14-day mouse fetus was used to hybridize with anti-sense strand (A) or sense strand (B) of the ect2 probe. B: br, brain; ol, olfactory lobe; hy, hypothalamus; nc, nasal cavities; tp, tooth primordium; th, thymus; he, heart; li, liver; lu, lung; cc, costal cartilage; pa, pancreas; gu, gut.

Figure 4B, ECT2 expression is induced as early as $6 \mathrm{~h}$ after serum addition, and reached to a peak 27-30 h after induction. Flow cytometric analyses indicated that the majority of the cells were in $\mathrm{S}$ phase $24 \mathrm{~h}$ after induction, whereas the percentage of cells in $\mathrm{G} 2 / \mathrm{M}$ phases were the highest $27-30 \mathrm{~h}$ after serum induction under these conditions. These results suggest that ECT2 expression is induced at $\mathrm{S}$ phase by serum and reached to the maximum at late $\mathrm{S}$ phase and G2/M phases. Examination of ECT2 mRNA revealed a similar expression pattern (Fig. 4C), suggesting that ECT2 expression is regulated at the transcriptional level.

\section{ECT2 Expression Is Regulated by Various Growth Factors}

To further investigate the regulation of ECT2 expression during cell proliferation, we examined whether ECT2 is also induced by growth factors. We first monitored mouse ect2 in serumstarved Balb/MK cells following the addition of keratinocyte growth factor (KGF), an epithelial cell-specific mitogen [Rubin et al., 1989]. In
Fig. 4. Induction of ECT2 by serum. A: Immunocytochemical detection of ECT2 before and after serum induction. M426 cells were stained for endogenous ECT2 by anti-ECT2 antibodies before and after serum-induction (upper panels). Nuclei of the cells were also stained with DAPI (lower panels). Similar experiments for NIH 3T3 mouse embryonic fibroblasts exhibited similar results. B: ECT2 protein expression in response to serum stimulation. T98G cells starved in $0.1 \%$ FBS for $72 \mathrm{~h}$ were stimulated to re-enter the cell cycle by the addition of fresh medium containing $10 \%$ FBS. Samples were harvested at the indicated time points, and analyzed by Western immunoblotting using the indicated antibodies. The blot was reprobed with anti$\alpha$-tubulin antibody to confirm equal loading of cellular components. A cell cycle profile is also shown, which contains percentages of cells in G0/G1, S, and G2/M phases at each time point obtained by flow cytometry. C: ECT2 mRNA expression in response to serum stimulation. Total RNA was extracted at the same time points as shown in (A) and analyzed by Northern blotting using ECT2-N4 CDNA as probe. $28 \mathrm{~S}$ ribosomal RNA was also detected for a loading control. 
A

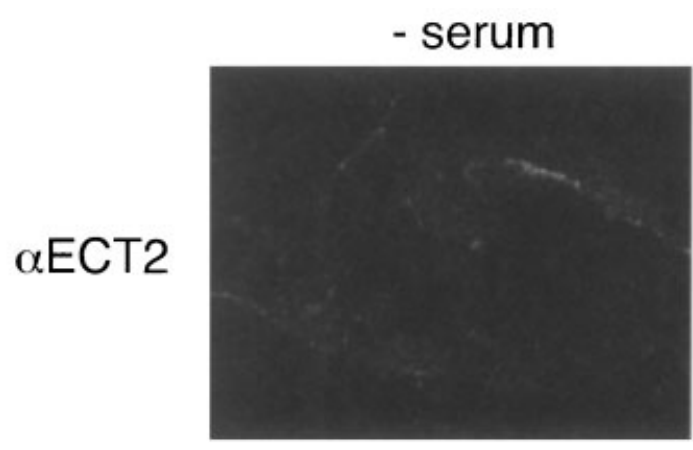

DAPI

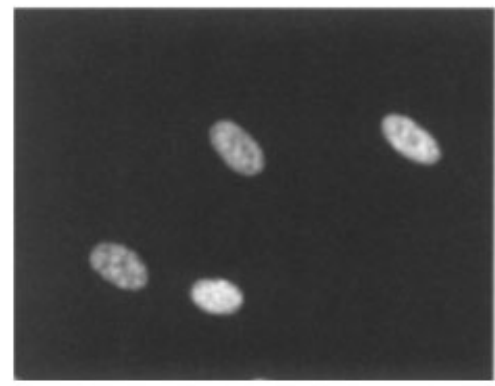

$+\operatorname{serum}(24 \mathrm{~h})$
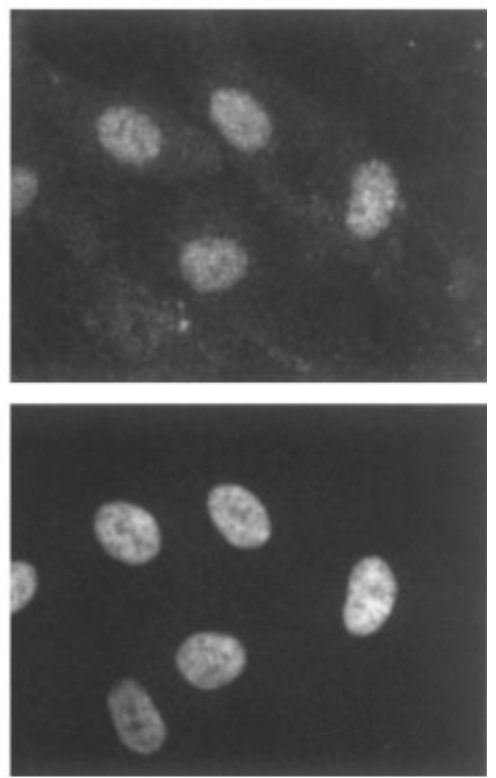

B $\quad$ Hours : $\quad \begin{array}{lllllllllll}0 & 6 & 12 & 15 & 18 & 21 & 24 & 27 & 30 & 33 & 36\end{array}$ ECT2 :

\section{Cyclin B1 :}

cdc2 :

$\alpha$-tubulin:

\begin{tabular}{r|r|r|r|r|r|r|r|r|r|r|r|}
\hline G0/G1 : & 91.9 & 90.6 & 86.5 & 87.3 & 79.3 & 65.7 & 19.7 & 15.2 & 54.0 & 73.4 & 77.9 \\
S : & 4.5 & 3.2 & 3.8 & 4.7 & 12.2 & 30.3 & 75.5 & 59.1 & 22.9 & 13.1 & 13.7 \\
\cline { 2 - 11 } G2/M : & 3.6 & 6.2 & 9.7 & 8.1 & 8.6 & 4.0 & 4.9 & 25.7 & 23.1 & 13.5 & 8.4 \\
\cline { 2 - 8 } & &
\end{tabular}

C

Hours : $\begin{array}{llllllllllll}0 & 6 & 12 & 15 & 18 & 21 & 24 & 27 & 30 & 33 & 36\end{array}$

\section{ECT2 :}

28S :

Fig. 4. 
serum-starved Balb/MK cells, the expression of ect2 was barely detectable (Fig. 5A, left panel). However, stimulation of Balb/MK by KGF resulted in a gradual increase that reached a peak after $48 \mathrm{~h}$ (9.7-fold increase when normalized with GAPDH signals). Ect2 transcript was induced by KGF at a concentration of $1 \mathrm{ng} / \mathrm{ml}$ and increased in a dose-dependent manner (Fig. 5A, right panel). A large induction of $\sim 100 \mathrm{kDa}$ Ect2 protein was observed in response to KGF in a time- and dose-dependent fashion (Fig. 5B). To determine in which phase of the cell cycle Ect2 was induced, we measured DNA synthesis following KGF treatment. The onset of Ect2 induction by KGF coincided with initiation of DNA synthesis determined by ${ }^{3} \mathrm{H}-$ thymidine incorporation (Fig. 5C). Similar to the induction kinetics by serum induction, ect2 induction was reached the maximum level after the peak of DNA synthesis.

To further test this correlation, we examined the effect of transforming growth factor- $\beta$ (TGF$\beta)$ on Ect2 expression. Consistent with its antiproliferative activity on Balb/MK cells, TGF- $\beta$ did not promote Ect2 expression during $48 \mathrm{~h}$ of treatment (Fig. 5D). Moreover, concomitant exposure to KGF and TGF- $\beta$ caused a delay in the onset of Ect2 induction relative to the pattern seen with KGF alone (compare Fig. 5D, lower panel with Fig. 5A, left panel). A similar delay was observed in the onset of DNA synthesis (data not shown).

Another mitogen for Balb/MK, epidermal growth factor (EGF), also exhibited a similar effect on ect 2 induction (Fig. 6A, lane 4). In contrast, hepatocyte growth factor (HGF)/scatter factor (SF) or insulin-like growth factor I (IGF-I) did not induce ect2 expression significantly even at higher concentrations than $\mathrm{KGF}$ (lanes 5 and 6). However, when these growth factors were added together, they could potently induce ect 2 expression (lane 7). These results were consistent with the observation that $\mathrm{HGF} /$ $\mathrm{SF}$ and IGF-I are weak mitogens for Balb/MK cells when tested separately, but have a potent synergistic effect when used in combination (Fig. 6B). Thus, there was a correlation between the stimulation of DNA synthesis and induction of Ect2.

We also found that platelet-derived growth factor (PDGF), the major mitogen in serum, induced ECT2 expression in a time-dependent manner (data not shown). Stimulation of fibroblasts with interleukin $1 \alpha$, a cytokine with potent proinflammatory activity, weakly elevated ECT2 mRNA levels, but transforming growth factor $\alpha$ (TGF- $\alpha$ ), a mitogen with activities in fibroblasts and epithelial cells, caused no significant variation in the levels of ECT2 mRNA (data not shown).

\section{ECT2-N Expression Generates Cells With High DNA Contents}

We have previously shown that ECT2-N can function as a dominant negative form of ECT2 and inhibits cytokinesis to generate multinucleate cells. To examine the inhibitory effect of ECT2-N on cytokinesis in detail, we utilized a flow cytometric analysis. U2OS cells were transiently transfected with the ECT2-N4 expression vector (see Fig. 8A) together with an expression vector for the membrane marker protein CD56, and then DNA contents of CD56positive cells were analyzed by flow cytometry (Fig. 7A). Vector alone or an expression vector for $\mathrm{p} 21^{\mathrm{WAF} 1}$ was used as controls. The vector alone transfectants were detected as peaks of cells with $2 \mathrm{~N}$ and $4 \mathrm{~N}$ DNA content, which represent G1 and G2 cells, respectively, whereas the majority of $\mathrm{p} 21^{\mathrm{WAF} 1}$ transfectants were in the $2 \mathrm{~N}$ peak, indicating that these cells arrested in G1. In contrast to the vector alone transfectants, ECT2-N4-expressing cells exhibited a higher population of $4 \mathrm{~N}$ cells than that of $2 \mathrm{~N}$ cells. Moreover, $48 \mathrm{~h}$ after transfection, ECT2N4 transfectants also contained cells with DNA contents higher than $4 \mathrm{~N}$, suggesting that these cells contain multiple nuclei. Concomitant to a decrease of the peaks of $2 \mathrm{~N}$ and $4 \mathrm{~N}$ cells of ECT2-N4 transfectants $96 \mathrm{~h}$ after transfection, an increase of the $8 \mathrm{~N}$ and $16 \mathrm{~N}$ peaks was observed (Fig. 7A). These results suggest that the accumulation of cells with $4 \mathrm{~N}$ DNA content was a transient event, and these $4 \mathrm{~N}$ cells subsequently became $8 \mathrm{~N}$ and $16 \mathrm{~N}$ cells. When ECT2-N4 expressing cells were treated with nocodazole, a microtubule de-stabilizing agent which arrests the cells at $\mathrm{M}$ phase, the generation of cells with 8N DNA content by ECT2-N expression was efficiently inhibited (Fig. 7B), suggesting that $8 \mathrm{~N}$ cells were produced from $4 \mathrm{~N}$ cells through $\mathrm{M}$ phase progression without cytokinesis. Similar effects of the expression of ECT2-N4 were also observed in other cell lines including HCT116, A549, and MCF7 (Fig. 8A), suggesting that the formation of cells with higher DNA contents is not a cell linedependent event. ECT2-N4 was efficiently 
A

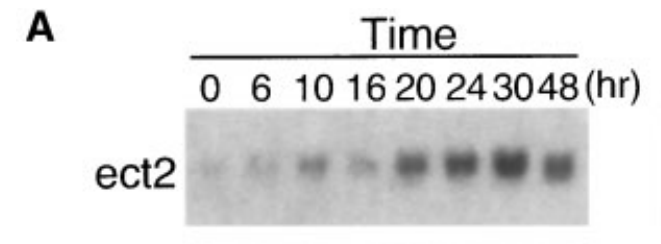

GAPDH

B

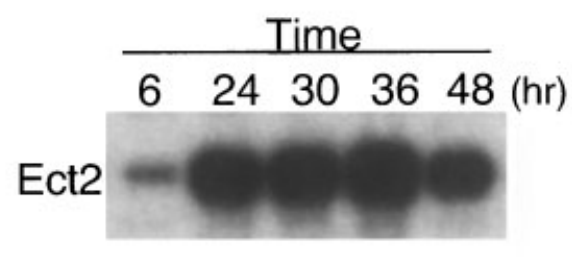

KGF concentration

\begin{tabular}{lllllll}
\hline 0 & 0.1 & 0.3 & 1.0 & 3.0 & 10 & $(\mathrm{ng} / \mathrm{ml})$
\end{tabular}

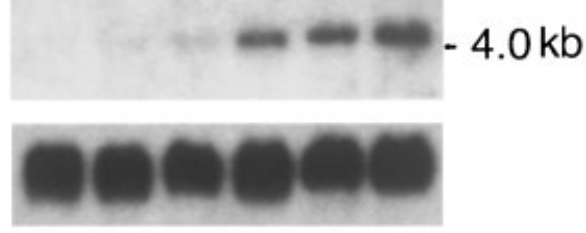

KGF concentration

$\begin{array}{lllll}0 & 0.31 .0 & 3.0 & 10 & (\mathrm{ng} / \mathrm{ml})\end{array}$

$-100 \mathrm{kDa}$

C

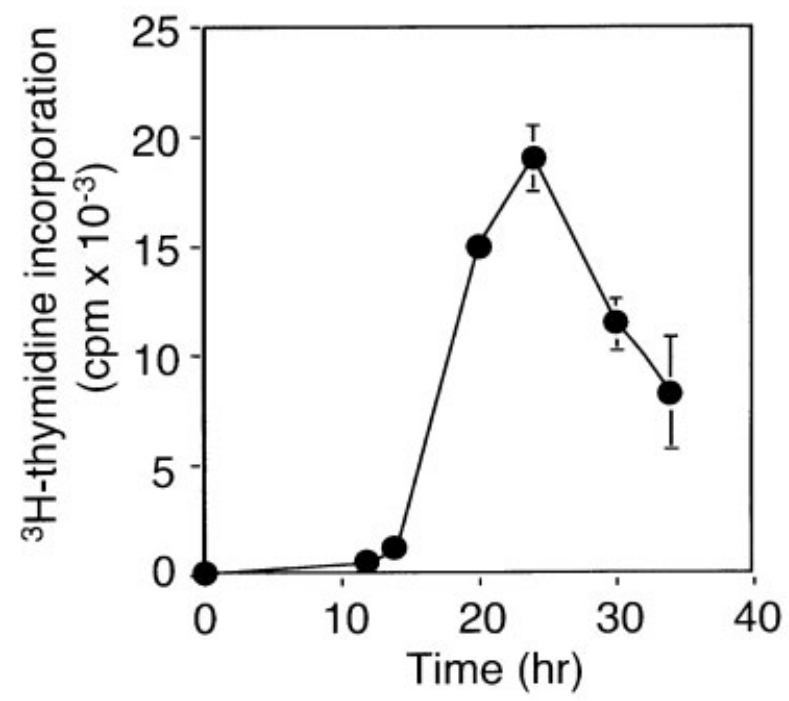

Fig. 5. Induction of ect $2 \mathrm{mRNA}$ and protein in Balb/MK cells. A (left panel): Expression of ect2 mRNA after addition of KGF to Balb/MK cells. Serum-starved Balb/MK cells were treated with KGF $(20 \mathrm{ng} / \mathrm{ml})$ and then harvested at the indicated time points. RNAs were analyzed by Northern blot hybridization with a mouse ect 2 cDNA as probe. GAPDH mRNA was monitored to assure similar loading of samples. Shown is a representative result of two independent experiments. Right panel: Doseresponse effect of KGF on ect2 mRNA expression. Quiescent Balb/MK cells were treated with various concentrations of KGF $(0-10 \mathrm{ng} / \mathrm{ml})$ for $30 \mathrm{~h}$ and ect2 transcript was analyzed by Northern blot hybridization. B (left panel): Time course of Ect2

expressed in U2OS, HCT116, and A549 (Fig. 8B). In MCF7, ECT2-N4 expression was lower than in other cell lines, and only a slight increase of the $4 \mathrm{~N}$ peak was observed. Expression of ECT2-F in U2OS cells also exhibited the higher $4 \mathrm{~N}$ peak than the $2 \mathrm{~N}$ peak $48 \mathrm{~h}$ after transfection (Fig. 7A), but cells with DNA protein induction by KGF $(10 \mathrm{ng} / \mathrm{ml})$ in Balb/MK cells. Right panel: Dose-dependent induction of Ect2 protein by KGF in Balb/ MK cells. Molecular size is indicated at the right. C: Kinetics of ${ }^{3} \mathrm{H}$-thymidine incorporation in Balb/MK cells after treatment with $\mathrm{KGF}(3 \mathrm{ng} / \mathrm{ml})$. Mean values $\pm \mathrm{SD}$ of triplicate measurements are shown. Shown is a representative result of two independent experiments. D: Effect of TGF- $\beta$ on ect 2 mRNA expression. Serum-starved Balb/MK cells were treated with TGF$\beta(1 \mathrm{ng} / \mathrm{ml})$ alone or KGF $(10 \mathrm{ng} / \mathrm{ml})$ plus TGF- $\beta(1 \mathrm{ng} / \mathrm{ml})$ for the indicated time periods. RNAs were visualized by Northern blot analysis with ect2 or GADPH cDNA probes. Shown is a representative result of two independent experiments.

content of higher than $4 \mathrm{~N}$ were not observed $96 \mathrm{~h}$ after transfection.

\section{Cytoplasmic Localization of ECT2-N Stimulates Multinucleate Cell Formation}

Using the flow cytometric analysis, we examined the effects of various ECT2-N derivatives 

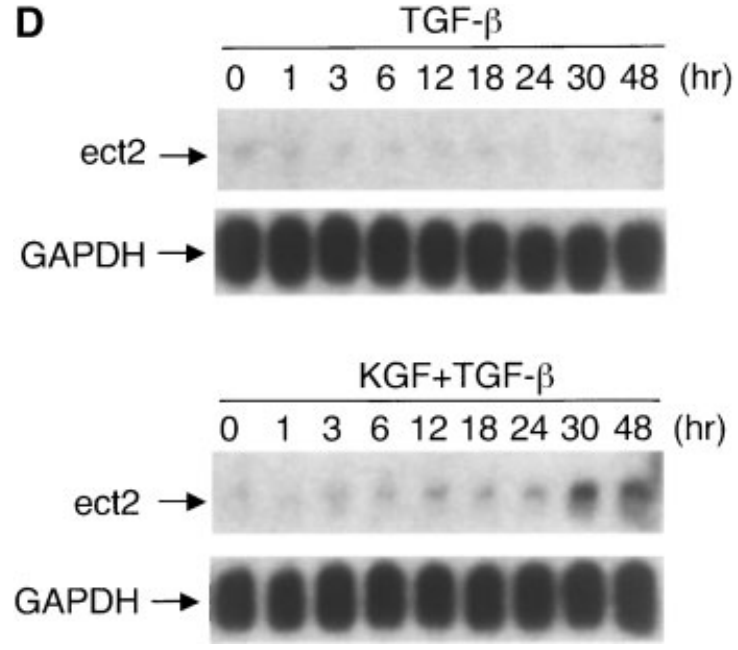

Fig. 5. (Continued)
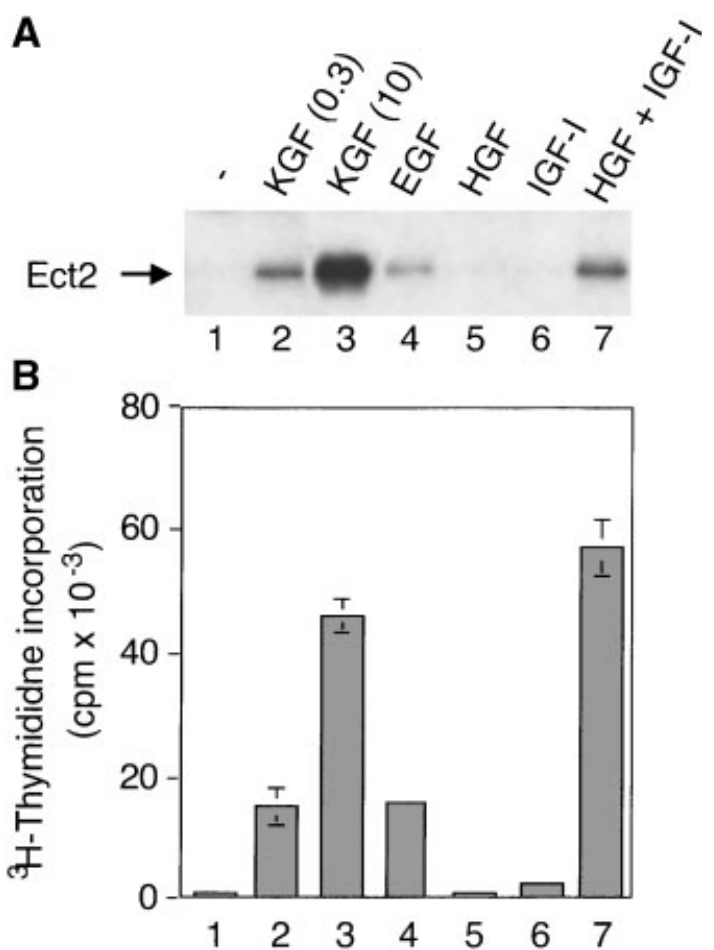

Fig. 6. Induction of Ect2 protein by growth factors. A: Immunoblot analysis of Ect 2 in Balb/MK cells in serum free medium in the absence of growth factors (lane 1), or in the presence of $0.3 \mathrm{ng} / \mathrm{ml} \mathrm{KGF}$ (lane 2), $10 \mathrm{ng} / \mathrm{ml} \mathrm{KGF} \mathrm{(lane} \mathrm{3),} 10 \mathrm{ng} / \mathrm{ml}$ EGF (lane 4), $20 \mathrm{ng} / \mathrm{ml} \mathrm{HGF/SF} \mathrm{(lane} \mathrm{5),} 200 \mathrm{ng} / \mathrm{ml} \mathrm{IGF-I} \mathrm{(lane} \mathrm{6),} \mathrm{or}$ $20 \mathrm{ng} / \mathrm{ml} \mathrm{HGF} / \mathrm{SF}$ plus $200 \mathrm{ng} / \mathrm{ml} \mathrm{IGF-I} \mathrm{(lane} \mathrm{7).} \mathrm{B:} \mathrm{Stimulation} \mathrm{of}$ DNA synthesis in growth factor-treated Balb/MK cells. Cultures were treated with various mitogens as in (A). DNA synthesis was measured by ${ }^{3} \mathrm{H}$-thymidine incorporation. Shown are the mean values $\pm S D$ of triplicate measurements from a representative experiment. Two independent experiments were performed. on cytokinesis. ECT2 contains two putative nuclear localization signals (NLSs) in a small central region, designated the $\mathrm{S}$ domain (Fig. 9A). We expressed ECT2-N derivatives as green fluorescent protein (GFP)-fusion proteins, and examined their subcellular localization (Fig. 9B). ECT2-F and ECT2-N1, which contain the intact $\mathrm{S}$ domain and thus both the NLSs, were predominantly localized in the nucleus. However, ECT2-N3, which contains only one of the NLSs, exhibited cytoplasmic localization, although the majority of the protein was still localized in the nucleus. In contrast to these proteins, ECT2-N4, which lacks both the NLSs, was localized in the cytoplasm as well as the nucleus. GFP alone was also localized to both the cellular compartments.

To test whether the subcellular localization affects the dominant negative effect of the ECT2-N proteins, DNA content of the transfectants was analyzed by flow cytometry as described above. To avoid the effects of cellular damage caused by transfection reagents, we estimate DNA content $72-90 \mathrm{~h}$ after transfection. While ECT2-N1 and ECT2-N2 as well as ECT2-F did not exhibit significant accumulation of cells with higher DNA content, ECT2-N3 and ECT2-N4 caused an increase of $4 \mathrm{~N}$ cells and appearance of $8 \mathrm{~N}$ and $16 \mathrm{~N}$ cells (Fig. 9A). The effect of ECT2-N4 on the generation of multinucleate cells was significantly higher than ECT2-N3, supporting the correlation between cytoplasmic localization and cytokinesis inhibition. The expression level of these GFP-ECT2 fusion proteins was comparable (Fig. 9C). These results suggest that cytoplasmic localization of ECT2-N strongly enhances the ability of ECT2$\mathrm{N}$ to inhibit cytokinesis.

\section{Cell Cycle/Repair Domains in ECT2-N Are all Required for Efficient Cytokinesis Inhibition}

We further tested which cell cycle/repair domains in ECT2-N are responsible for cytokinesis inhibition. For this purpose, a deletion or mutation was introduced in each of the domains in ECT2-N4, which exhibited a strong inhibitory effect on cytokinesis. Interestingly, changes of the conserved amino acid residues (THL to AAA) in either of the BRCT repeats of ECT2-N4 efficiently abolished the appearance of multinucleated cells (Fig. 9A), suggesting that each of these repeats is essential for the inhibition of cytokinesis. Additionally, ECT2- 
A Vector
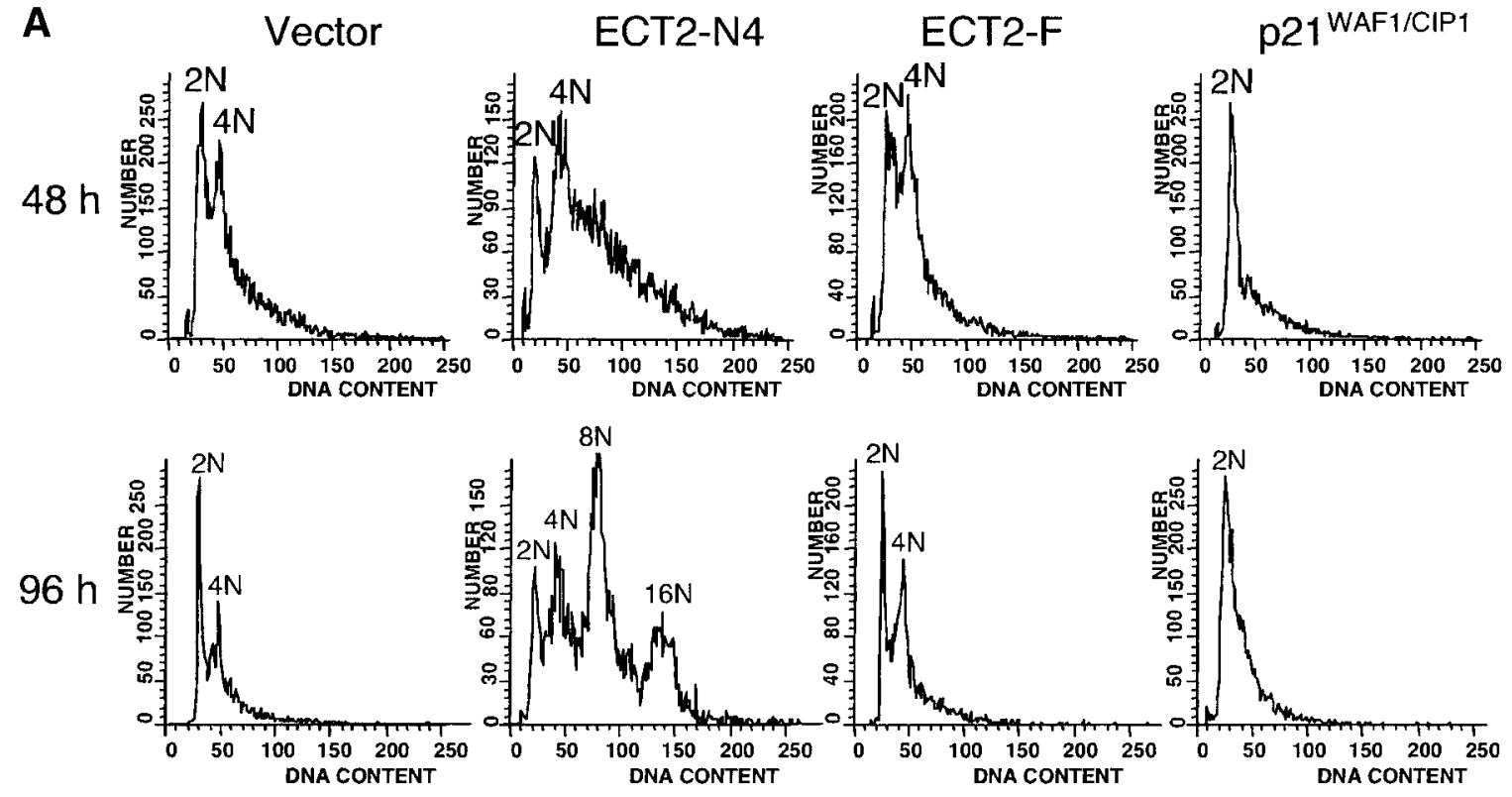

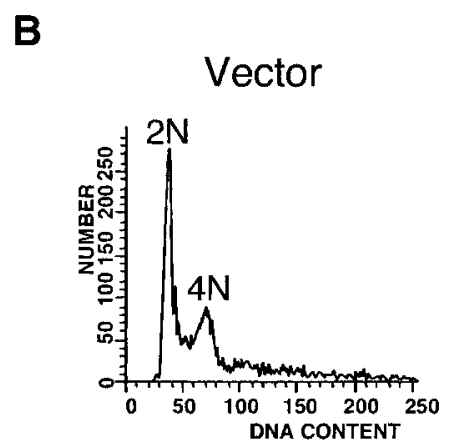

Fig. 7. Analysis of DNA content of U2OS cells expressing ECT2. A: U2OS cells were transiently transfected with the empty vector or the ECT2-N4 or p21 WAF1 expression vector, together with the CD56 expression vector. Transfectants were FACSsorted for CD56 marker expression and their DNA contents analyzed following propidium iodide staining $48 \mathrm{~h}$ (upper panels) or $96 \mathrm{~h}$ (lower panels) after transfection. B: U2OS cells

N5, an ECT2-N4 derivative lacking the Cterminal half of BRCT repeat 2, did not significantly inhibit cytokinesis. Moreover, a small internal deletion in the CLB6 domain or an Nterminal deletion extending to the XRCC1 domain also abolished the ability of ECT2-N to inhibit cytokinesis. In contrast, a small Nterminal deletion $(\mathrm{ECT} 2-\mathrm{N} 4 \Delta \mathrm{N})$, which does not extend to the XRCC1 domain, did not affect the activity. The expression level of these exogenous proteins was comparable as detected by immunoblotting using anti-ECT2 antibody (data not shown). These results strongly suggest that all of the XRCC1, CLB6, BRCT-1, and

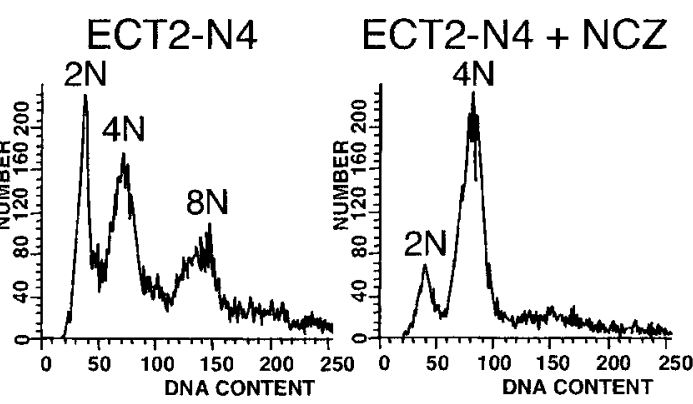

were transfected with the ECT2-N4 and CD56 expression vectors and cultured as above except that nocodazole was added at a final concentration of $0.4 \mu \mathrm{g} / \mathrm{ml}, 18 \mathrm{~h}$ after transfection (+NCZ). Transfectants were FACS-sorted for CD56 marker expression and their DNA contents analyzed following propidium iodide staining $72 \mathrm{~h}$ after transfection.

BRCT-2 domains play a crucial role in regulating cytokinesis.

\section{DISCUSSION}

Human ECT2 contains cell cycle regulator/ checkpoint control protein-related domains in the N-terminal half. Drosophila $\mathrm{Pbl}$ and C. elegans $\mathrm{T} 19 \mathrm{E} 10.1 \mathrm{~b}$ proteins exhibited structural similarities to ECT2 in the entire stretch of their open-reading frames, suggesting that these are fly and worm orthologs, respectively. These ECT2 orthologs, as well as human Rad4like (accession no. Z46795) and C. elegans 
A
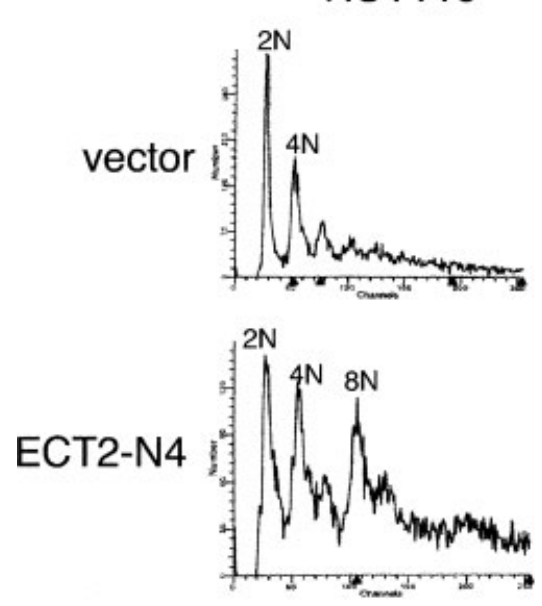

A549
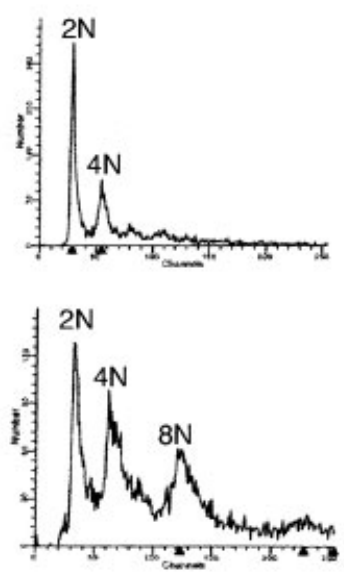

MCF7
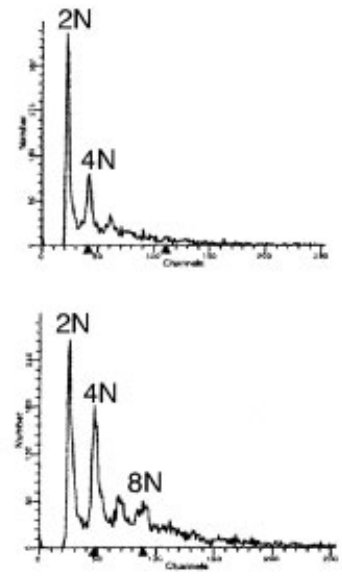

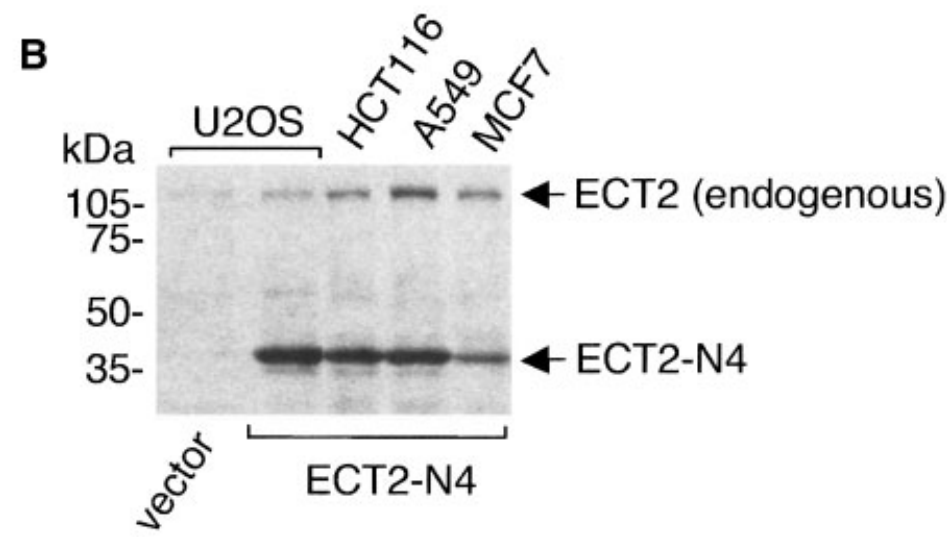

Fig. 8. Analysis of DNA content of HCT116, A549, and MCF7 expressing ECT2-N. A: HCT116 (human colon carcinoma), A549 (human lung carcinoma), and MCF7 (human mammary carcinoma) cells were transfected with ECT2-N4 or vector alone

F37D6.1 (accession no. Z75540) genes, contain the BRCT repeats, which are also found within many DNA damage repair and cell cycle checkpoint control proteins [Bork et al., 1997]. BRCT domains are 85-95 amino acid domains that comprise several distinct clusters of conserved hydrophobic amino acids that together form the core of the BRCT fold [Huyton et al., 2000]. together with CD56, and analyzed as in the legend to Figure $1 \mathrm{~A}$ $96 \mathrm{~h}$ after transfection. B: Expression levels of endogenous ECT2 and exogenously expressed ECT2-N4 as detected by immunoblotting by anti-ECT2 antibody.

There is no invariant amino acid residue throughout the whole BRCT superfamily and this lack of sequence identity makes recognition of distant family members difficult. However, the comparison of the domains among those which are most homologous to ECT2 suggests several conserved regions (Fig. 1C). The Nterminal tandem BRCT repeats of Cut5 interact
Fig. 9. Determination of the domains responsible for multinucleate cell formation by ECT2-N. A: Structure of ECT2 derivatives and their ability to generate multinucleate cells. Regions carried by ECT2 expression vectors are shown below the schematic structure of ECT2. Location and amino acid sequence of tandem NLSs are also shown. Numbers denote amino acid numbers. $X$ indicates location of mutations (THL to AAA). The positions of these mutations are also shown by "****" in Figure 1B. Multinucleate cell generation was estimated by flow cytometry as in the legend to Figure $7 .-,<5 \% ;+, 20 \sim 50 \% ;++,>50 \%$ of $8 \mathrm{~N}$ and $16 \mathrm{~N}$ cells in the CD56 positive cell population. B:
Subcellular localization of GFP-ECT2 fusion proteins. The CDNAs were cloned in pEGFPC1 vectors and used to transfect U2OS cells. Forty-eight hours after transfection, Hoechst 33342 dye was added to culture medium at a final concentration of $10 \mu \mathrm{M}$ and cells were directly observed under the fluorescence microscope and photographed. The GFP fusion proteins and nucleus were visualized by green fluorescence and Hoechst 33342 (blue), respectively (magnification, 400×). Merged images are shown at the bottom. C: Expression levels of GFPECT2 fusion proteins. The fusion proteins were detected by antiGFP antibody. 
A
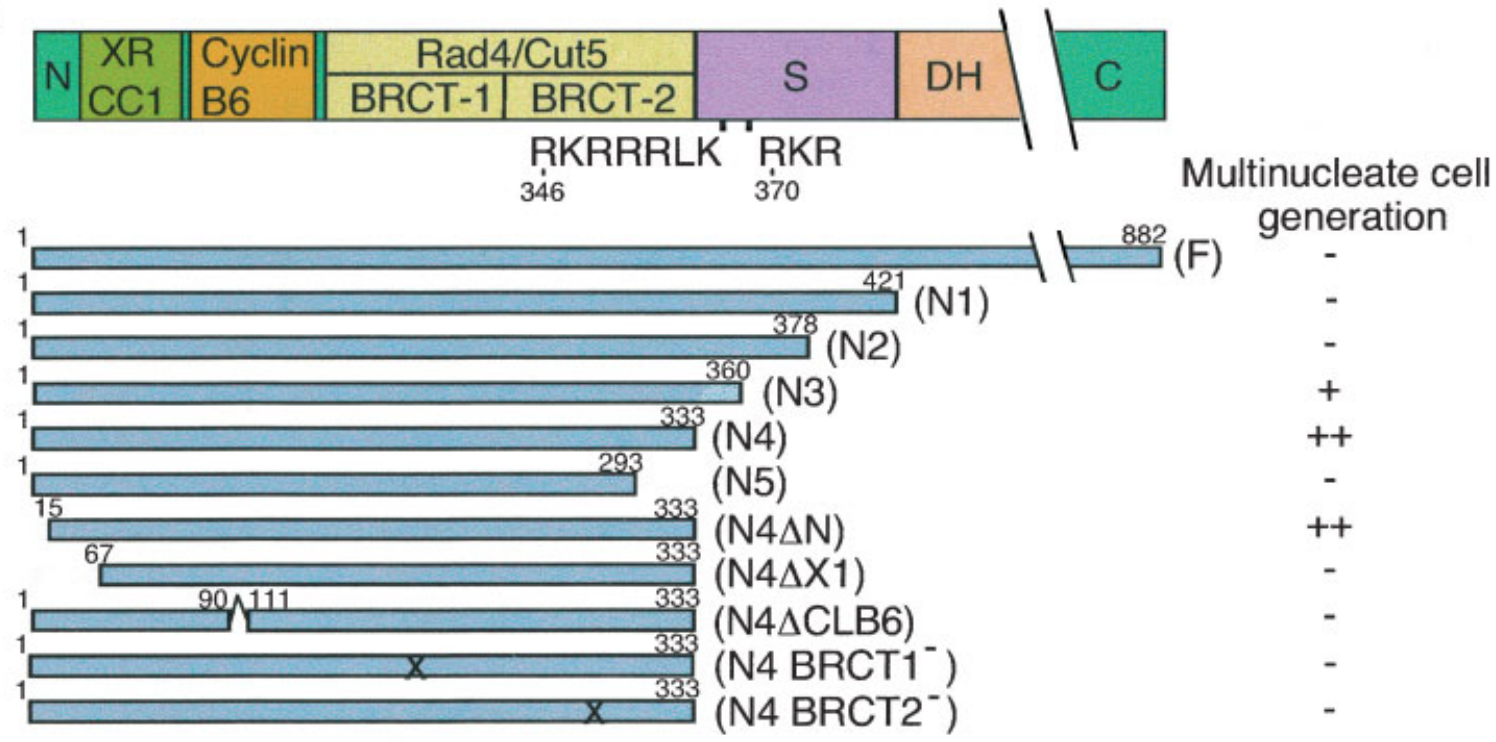

B
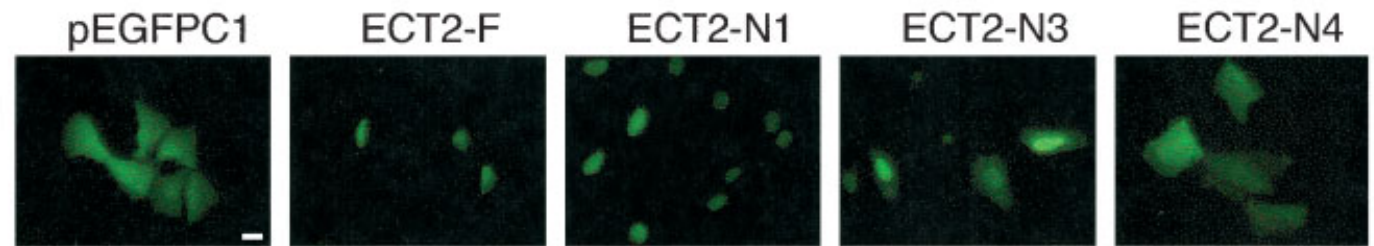

DNA
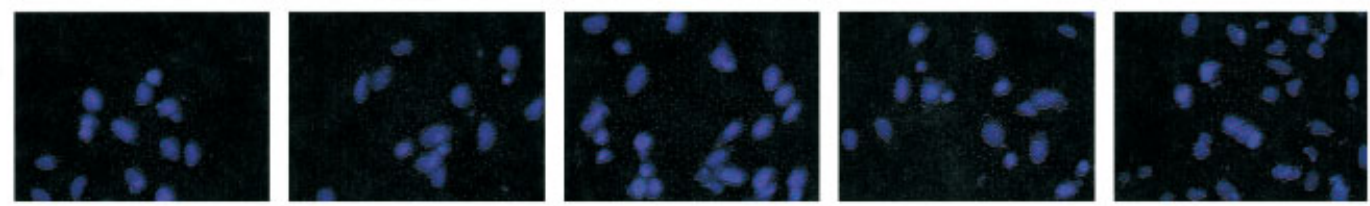

Merge
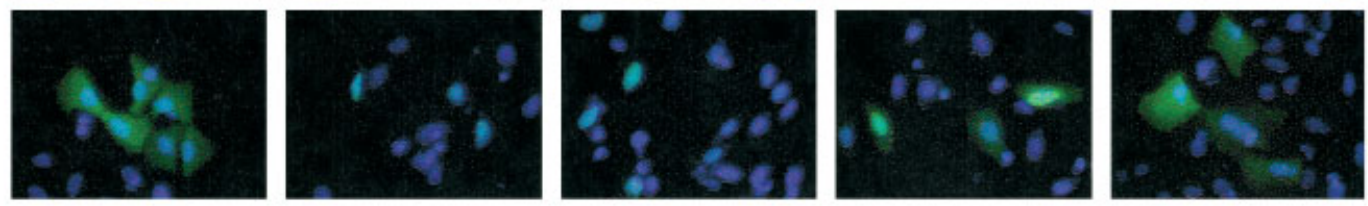

C

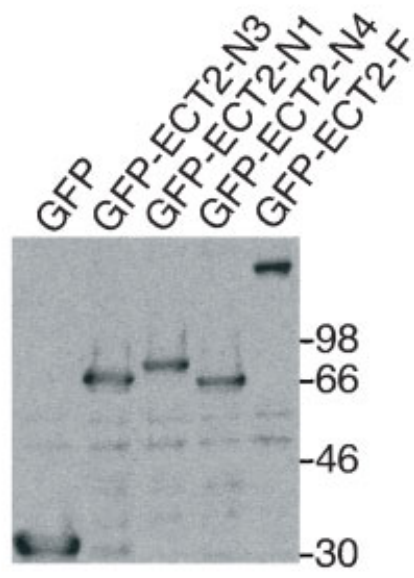

Fig. 9. 
with another checkpoint control protein Crb2, which is closely related to the budding yeast checkpoint control protein Rad9 [Saka et al., 1997]. Since ECT2 BRCT domains are most homologous to the N-terminal two BRCT repeats of Cut5 among the known BRCT domains, ECT2 BRCT domains may also associate with certain molecules such as checkpoint control proteins to transmit the signals to downstream molecules.

The BRCT repeats in ECT2 were also closely related to those of the human repair protein XRCC1 [Thompson et al., 1990] and human topoisomerase II-binding protein TopBP1 [Yamane et al., 1997]. ECT2 also contains the XRCC1-related domain besides the BRCT repeats (Fig. 1). Recently, it has been shown that the Xenopus ortholog of human TopBP1 is involved in initiation of DNA replication through chromatin binding [Hashimoto and Takisawa, 2003]. A domain homologous to the yeast $S$ phase cyclin CLB6 was identified in ECT2 between the XRCC1 domain and the BRCT repeats. The new type pair of yeast B-cyclins CLB5 and CLB6 are involved in DNA replication [Schwob and Nasmyth, 1993]. An interesting finding is that these cyclins are required for premeiotic DNA replication and activation of the meiotic S/M checkpoint [Stuart and Wittenberg, 1998]. As ECT2 is localized in the nucleus of interpahse cells [Tatsumoto et al., 1999], ECT2 may function in DNA replication, repair, and/or checkpoint control through the XRCC1, CLB6, and BRCT domains.

ECT2 expression was markedly high in mouse embryonic tissues containing rapidly proliferating cells. Moreover, ECT2 is also expressed at high levels in various tumor cell lines, which are also growing rapidly. Most of the ovarian and bladder carcinomas examined, exhibited elevated ECT2 expression. The expression level of ECT2 was highest in a lung carcinoma cell line A549 and colon carcinoma SW480. These results may indicate that elevated ECT2 expression stimulates cell proliferation. In contrast to the overexpression of ECT2 in various tumor cell lines, there was no evidence for structural alterations of the gene, although more studies will be needed to solve the question. Stimulation of resting cells to reenter the cell cycle by serum and growth factors is followed by a rapid, and sometimes transient, activation of a group of primary response genes, whose expression is believed to initiate and to be critical for the establishment of the cellular responses to these stimuli. Our results demonstrated that serum and several growth factors promoted a significant elevation of ECT2 expression. Unlike immediate early genes that are induced by serum at G1 phase, ECT2 induction occurred in $\mathrm{S}$ phase and gradually increases towards its maximum in G2/M. Increase of both ECT2 mRNA and protein in S, G2, and M phases of the cell cycle suggests a possible function of ECT2 in these phases of the cell cycle. As the present results support that ECT2 is a critical regulator of cytokinesis, increased expression of ECT2 in M phase is consistent with its biological function. However, induction of ECT2 is in coincidence with the onset of S phase, suggesting that ECT2 may have an additional function in S phase. As discussed above, the BRCT motif provided impetus for the present study because of the association of this domain with proteins that participate in checkpoint control of the cell cycle.

We examined the effect of ECT2-N on cell division in U2OS cells using flow cytometry. The majority of cells expressing ECT2-N were detected as cells with $4 \mathrm{~N}$ or higher DNA contents, which is consistent with the previous result that ECT2-N can function as a dominant negative mutant and induces multinucleate cell formation [Tatsumoto et al., 1999]. Using this assay, we found a correlation between cytoplasmic localization of ECT2-N and inhibition of cytokinesis. ECT2 disperses to the entire cells after nuclear membrane breakdown and then accumulates in the midbody [Tatsumoto et al., 1999]. To display the dominant negative effect towards cytokinesis, ECT2-N must compete with endogenous ECT2 for binding to the sites where it regulates cytokinesis. When ECT2-N is present in the cytoplasm before nuclear membrane breakdown, it may pre-emptively occupy the ECT2 binding sites, which will later become a component of the regulatory site for cytokinesis. Therefore, it is likely that ECT2-N derivatives lacking NLSs can localize in the cytoplasm before the endogenous ECT2 reaches to this compartment, and therefore, can strongly display its dominant-negative effect to inhibit cytokinesis.

Mutational analysis revealed that each of XRCC1, CLB6, BRCT-1, and BRCT-2 domains is required for the inhibitory effect of ECT2-N on cytokinesis. Thus, these domains might play a critical role to regulate cytokinesis by ECT2. 
The BRCT motif can function as a proteinprotein interaction site as discussed above. Besides the BRCT domains, the XRCC1 homology domain may also have such a function. The CLB6 domain is homologous to a region of budding yeast cyclin $\mathrm{B} 6$ between the cyclin box and destruction box. This region may also function as a binding site to other proteins. Collectively, the cell cycle/repair domains of ECT2 may function as the binding sites of upstream signaling molecules and/or scaffold proteins, which can determine the localization of ECT2 to the site where it regulates cytokinesis. As $\mathrm{N}$-terminal truncation of ECT2 activates its transforming activity [Miki et al., 1993], ECT2$\mathrm{N}$ appears to interact with the catalytic domain to negatively regulate the exchange activity. Therefore, association of ECT2 at its N-terminal domain with upstream molecules may activate the exchange activity of ECT2 by dissolving the negative regulation. Some of the upstream molecules may localize at the site for cytokinesis. Thus, such a regulatory mechanism may allow ECT2 to activate Rho GTPases at a spatiotemporal manner, which is required for the precise control of cytokinesis. Further studies of ECT2 and identification of its binding proteins will clarify the molecular mechanisms of cytokinesis as well as yet undiscovered functions of ECT2.

\section{ACKNOWLEDGMENTS}

We thank Dr. J. Pierce, Dr. L. Samelson, and Dr. D. Lowy for support; Dr. Cecil Fox for assistance with in situ hybridization; Dr. Jerry Ward for discussion of ect2 expression in embryos; and Ricardo Dreyfuss for photography. T.T was supported by Japan Society of Promotion of Sciences fellowships for Biomedical and Behavioral Researchers in NIH.

\section{REFERENCES}

Bork P, Hofmann K, Bucher P, Neuwald AF, Altschul SF, Koonin EV. 1997. A superfamily of conserved domains in DNA damage-responsive cell cycle checkpoint proteins. FASEB J 11:68-76.

Cioce V, Csaky KG, Chan AM, Bottaro DP, Taylor WG, Jensen R, Aaronson SA, Rubin JS. 1996. Hepatocyte growth factor (HGF)/NK1 is a naturally occurring HGF/ scatter factor variant with partial agonist/antagonist activity. J Biol Chem 271:13110-13115.

Fox CH, Cottler-Fox M. 1993. In situ hybridization in HIV research. Microsc Res Tech 25:78-84.

Hall A. 1998. Rho GTPases and the actin cytoskeleton. Science 279:509-514.
Hashimoto Y, Takisawa H. 2003. Xenopus Cut5 is essential for a CDK-dependent process in the initiation of DNA replication. EMBO J 22:2526-2535.

Huyton T, Bates PA, Zhang X, Sternberg MJ, Freemont PS. 2000. The BRCA1 C-terminal domain: Structure and function. Mutat Res 460:319-332.

Kimura K, Tsuji T, Takada Y, Miki T, Narumiya S. 2000. Accumulation of GTP-bound RhoA during cytokinesis and a critical role of ECT2 in this accumulation. J Biol Chem 275:17233-17236.

Lorenzi MV, Castagnino P, Chen Q, Hori Y, Miki T. 1999. Distinct expression patterns and transforming properties of multiple isoforms of Ost, an exchange factor for RhoA and Cdc42. Oncogene 18:4742-4755.

Miki T, Smith C, Long J, Eva A, Fleming T. 1993. Oncogene ect 2 is related to regulators of small GTP-binding proteins. Nature 362:462-465.

Prokopenko SN, Brumby A, O'Keefe L, Prior L, He Y, Saint R, Bellen HJ. 1999. A putative exchange factor for Rho1 GTPase is required for initiation of cytokinesis in Drosophila. Genes Dev 13:2301-2314.

Ron D, Bottaro DP, Finch PW, Morris D, Rubin JS, Aaronson SA. 1993. Expression of biologically active recombinant keratinocyte growth factor. Structure/ function analysis of amino-terminal truncation mutants. J Biol Chem 268:2984-2988.

Rubin JS, Osada H, Finch PW, Taylor WG, Rudikoff S, Aaronson SA. 1989. Purification and characterization of a newly identified growth factor specific for epithelial cells. Proc Natl Acad Sci USA 86:802-806.

Saito S, Inoue T, Kawase I, Hara H, Tanio Y, Tachibana I, Hayashi S, Watanabe M, Matsunashi M, Osaki T, Masuno T, Kishimoto S. 1991. Two monoclonal antibodies against small-cell lung cancer show existence of synergism in binding. Cancer Immunol Immunother 33:165-170.

Saito S, Tanio Y, Tachibana I, Hayashi S, Kishimoto T, Kawase I. 1994. Complementary DNA sequence encoding the major neural cell adhesion molecule isoform in a human small cell lung cancer cell line. Lung Cancer 10: 307-318.

Saka Y, Yanagida M. 1993. Fission yeast cut5+, required for $\mathrm{S}$ phase onset and $\mathrm{M}$ phase restraint, is identical to the radiation-damage repair gene $\mathrm{rad4}^{+}$. Cell 74:383393.

Saka Y, Fantes P, Sutani T, McInerny C, Creanor J, Yanagida M. 1994. Fission yeast cut5 links nuclear chromatin and $\mathrm{M}$ phase regulator in the replication checkpoint control. EMBO J 13:5319-5329.

Saka Y, Esashi F, Matsusaka T, Mochida S, Yanagida M. 1997. Damage and replication checkpoint control in fission yeast is ensured by interactions of $\mathrm{Crb2}$, a protein with BRCT motif, with Cut5 and Chk1. Genes Dev 11: 3387-3400.

Sakata H, Rubin JS, Taylor WG, Miki T. 2000. A Rhospecific exchange factor Ect2 is induced from $\mathrm{S}$ to $\mathrm{M}$ phases in regenerating mouse liver. Hepatology 32:193199 .

Schwob E, Nasmyth K. 1993. CLB5 and CLB6, a new pair of B cyclins involved in DNA replication in Saccharomyces cerevisiae. Genes Dev 7:1160-1175.

Stuart D, Wittenberg C. 1998. CLB5 and CLB6 are required for premeiotic DNA replication and activation of the meiotic S/M checkpoint. Genes Dev 12:2698-2710. 
Takai S, Long JE, Yamada K, Miki T. 1995. Chromosomal localization of the human ECT2 proto-oncogene to $3 q 26.1->$ q26.2 by somatic cell analysis and fluorescence in situ hybridization. Genomics 27:220-222.

Tatsumoto T, Xie X, Blumenthal R, Okamoto I, Miki T. 1999. Human ECT2 is an exchange factor for Rho GTPases, phosphorylated in G2/M phases, and involved in cytokinesis. J Cell Biol 147:921-927.

Thompson LH, Brookman KW, Jones NJ, Allen SA, Carrano AV. 1990. Molecular cloning of the human
XRCC1 gene, which corrects defective DNA strand break repair and sister chromatid exchange. Mol Cell Biol 10: 6160-6171.

Van Aelst L, D’Souza-Schorey C. 1997. Rho GTPases and signaling networks. Genes Dev 11:2295-2322.

Yamane K, Kawabata M, Tsuruo T. 1997. A DNAtopoisomerase-II-binding protein with eight repeating regions similar to DNA-repair enzymes and to a cell-cycle regulator. Eur J Biochem 250:794-799. 